\title{
Improving Professional IT Doctorate Completion Rates
}

\author{
Oliver K. Burmeister \\ School of Computing and Mathematics \\ Charles Sturt University, Bathurst, Australia \\ oburmeister@csu.edu.au
}

\begin{abstract}
Professional doctorates in Information Technology (IT) have been a relatively recent phenomenon, giving IT professionals career management choices not previously available to them. However, successful completion rates are the lowest of all disciplines. Completed doctorates rate in quality equivalent to $\mathrm{PhDs}$, and retention has been identified as a major obstacle to completion. This qualitative study, involving 44 semi-structured interviews with students, supervisors and institutional support personnel, investigated the obstacles. Amongst the strategies discovered to improve completion rates were retention, student engagement with supervisors, feedback on progress, student engagement in the course, and student involvement in institutional communities of practice.
\end{abstract}

Keywords: Career management, community of practice, postgraduate education, retention.

\section{Introduction}

It is disappointing that information technology (IT) doctorates have the worst completion rates of all professional doctorates. That makes the choice to invest significant money and time into career advancement through postgraduate study an even more difficult choice for professionals in IT, than it does for those in education, business and other disciplines. Although there exists an extensive literature on the professional doctorate and postgraduate education relating to doctorates, it is predominantly in education and on full-time research. Comparatively little research has been conducted into part-time professional doctorates in IT. The present study aimed to improve completion rates in IT doctorates. It examined multiple contributing factors, including support structures, curriculum design, supervisory capacity and student perspectives, by drawing on 44 interpretive interviews with students, supervisors and support staff. It makes recommendations about better student recruitment, more integrated preparation for the research component, ways to better resource students and supervisory teams, and draws on lessons in other disciplines to recommend how to reduce attrition and improve successful completion.

Career management literature, including career construction theory (Guan et al., 2014) and subjective career success ( $\mathrm{Ng} \&$ Feldman, 2014), have demonstrated that in the modern world people are readily changing jobs to achieve career aspirations and many are willing to pursue further training, including advanced tertiary education. The latter is because it is seen as an "entry into many high-paying and high-status occupations" (Ng \& Feldman, 2014, p. 172). Recent literature on IT doctorates has called for the development of doctorates that are not focused on pure research $(\mathrm{PhD})$, but which address the needs of practicing professionals, for example, one that argued that no such program existed in the state of Georgia and proposed such a program (Hoganson \& Amoroso, 2011). However, perhaps because of the recency of such IT doctorates, unlike other disciplines, where curriculum design is discussed, the approach is rarely evaluated (Hoganson \& Amoroso, 2011; Merritt et al., 2004). A further contribution of this article is that it describes the curriculum design and evaluates the efficacy of the program.

There are different types of doctoral programs, including not only the Doctor of Philosophy (PhD), but also various full-time and part-time professional doctorates, such as the Doctor of Business Administration, and the Doctor of Information Technology (DIT). A DIT for this study is a part-time doctorate typically undertaken by mid-career professionals from various IT backgrounds, including computer science and information systems, who seek to move into 
more managerial roles within their respective organisations. The article begins with a review of professional doctorates. Then the methodology for the study is detailed, including the course design. That is followed by a discussion of the results, in which implications are drawn in relation to policy, managing doctoral IT courses, vocational choices, supervisory training, and resourcing issues.

\section{Doctoral Education}

Doctoral studies focus on the $\mathrm{PhD}$ (Metcalfe \& Kiley, 2000), and on supervision practices, as opposed to student perspectives (Fink, 2006; Lee \& McKenzie, 2011), although professional doctorates have been the subject of research for the past two decades (Fink, 2006; Lee, Brennan, \& Green, 2009). As one might expect, the self-reflective nature of educational research is seen in that the dominant research into doctorates, both $\mathrm{PhD}$ and professional, has taken place in education-related disciplines (Green, 2012; Lee et al., 2009; Lee, Green, \& Brennan, 2000). IT doctorates are poorly represented in the literature (Hirschheim \& Klein, 2012), often subsumed under science doctorates.

Numerous initiatives have taken place, particularly in Europe, to define what constitutes a doctorate. Tracing European developments, Lee (2009) referred to the 1999 Bologna Declaration, and examined the 2004 Lisbon Agenda, the 2005 Bergen Communiqué, and other doctoral reviews, which the European Union saw as a way of streamlining the lengthy $\mathrm{PhD}$ process to "last 3-4 years and [because] they wanted programmes to meet the wider needs of the employment market" (Lee, 2009, p.2).

\subsection{Completion rates and attrition risks in doctoral programs}

Completion rates are closely associated with attrition risks. A concerted effort at the Graduate School of Arts and Sciences, University of Texas, lifted doctoral completion rates from $34 \%$ to $70 \%$ over a 10 year period to 2004 (Smallwood, 2004). A twelve-year study of completion rates, involving 30 institutions, revealed that doctoral programs in mathematics and physical sciences (including computer science) had the second lowest completion rates, of $55.5 \%$. Of all the discipline-specific categories investigated, computer science had the lowest completion rate, of 41\% (Sowell, 2008). Australian data shows that at Monash University across all disciplines, completion rates were approximately 40\% in 1994-1996, but that by focusing on improving this, their Faculty of Arts improved completion to above 70\% by 2008 (Cuthbert, 2008).

Poor completion rates in IT are of particular concern for developing nations, because the development of IT infrastructure is often seen as vital in the effort to keep up with more developed nations. For example, one South African study revealed that from 2000-2007 there were 1,039 doctoral graduates, with $26 \mathrm{PhD}$ graduates per million people (Kritzinger \& Loock, 2012, p. 2). In 2007 "7\% were from engineering and technology" (Kritzinger \& Loock, 2012, p. 3). Focusing on the University of South Africa's (Unisa) School of Computing, they found that "few students graduate" (Kritzinger \&Loock, 2012, p. 11), with no graduates in 2007 and 2010, and that for those who did, the average time to completion was 4.2 years. 2010 data revealed that in Information Systems the doctoral dropout rate was $50 \%$ in the first year and $66.7 \%$ for Computer Science, averaging 55\%. They concluded that "The dropout rates of master's and doctoral students is currently the most vulnerable aspect contributing to the low postgraduate success rate." (Kritzinger \& Loock, 2012, p. 15) That finding is mirrored by an earlier study in the USA, which experienced a 70\% dropout rate, but for the students who graduated, the quality of their work was of a high standard (Merritt et al., 2004). This suggests that more effort needs to focus on retaining doctoral IT students within a program, that is, that in order to increase successful completion, efforts need to focus on retention.

The role of supervisors in student progression has been extensively explored, particularly in relation to PhDs and within that on supervisory capacity (Engebretson et al., 2008; McCallin \&Nayar, 2012). However, literature which addresses student progression in doctoral programs is less common (Cumming \& Kiley, 2011, p. 14). Literature on supervisory capacity includes 
recommendations to reduce supervisory workload requirements through doctoral coursework, which is the dominant model for professional doctorates, but less common for PhDs (Alpert \& Kamins, 2004; Kiley, 2012); to increase training in supervision (Amundsena \& McAlpine, 2009; Kiley, 2012; McAlpine \& Amundsen, 2012), particularly for people new to academia (Blass, J asman, \& Levy, 2012; Christine Halse, 2011; C. Halse \& Malfroy, 2010), which is the case for industry co-supervisors; to better cater to the growing demand for off-campus study and therefore for distance supervision (Andrew, 2012; Crossouard, 2008; Crossouard \& Pryor, 2009; Erichsen, Bolliger, \& Halupa, 2012); and, group supervision (Berteau \& Villeneuve, 2006; Fenge, 2012). A topic insufficiently addressed in the literature is the workload demands and capacity to supervise of industry supervisors. These are typically senior people in industry who volunteer to become, typically unpaid, secondary supervisors (Pavlova \& Silbereisen, 2014). Volunteering can show leadership in one's discipline and is also a way of giving back, of making a contribution to the discipline and to the next generation of professionals therein.

\subsection{Communities of practice}

Traditional pedagogical research concerning workplace learning is focused on training undergraduate students for the workplace. However, professional doctorates are typically undertaken by people in mid-career and therefore the nature of the education-workplace mixture does not fit with those traditional pedagogies. The closest conceptual framework is the concept of communities of practice $(\mathrm{CoP})$. $\mathrm{CoP}$ is a synthesis of pedagogies and epistemological foundations which facilitates the encompassing of research education into professional practice (Kimmerle et al., 2013; Loftus, 2010). That is, whereas workplace learning, practicebased education and related traditional formulations have sought to involve relatively 'uninitiated' students in professional practice during their education, professional doctorates seek to bring research related education into the professional practice of experienced practitioners. For instance, one study reported that for professional doctorates "Entering students' careers extend from five to 33 years, with an average among students of 13 years" (Grossman, Tappert, Bergin, \&Merritt, 2011, p. 135). Thus professional doctorates are typically undertaken by mature students, frequently in middle to senior roles, who work demanding jobs, whilst engaged in their studies. This distinction is important and has long been recognised, as illustrated by Schön's (1987) claim that beginners in any profession cannot fully appreciate what the work involves until they have been completely immersed in the work routines for some time. That is, there exists a fundamental difference in the nature of professional practice, when engaged in by a student on work placement who has little professional experience, and a person who is engaged in professional development activities of an educational nature, who has extensive industry experience. Following his review of the CoP literature, Loftus defined it as follows (Loftus, 2010, pp. 41-42): Communities of practice are groups of people who share an interest in something that they do. A key insight is that people learn how to do their practice better as they interact regularly.

As one recent study reported, the types of skill training required in information systems at an undergraduate level is more technically oriented, whereas at a postgraduate level, soft skills are required (Richards \& Marrone, 2014). In another study Barnett and Coate (2005) argued that the aim of educational experiences was to assist students to become professional practitioners. However professional doctorates are undertaken by people who are already professional practitioners and but who are not yet researchers.

In summary, doctorates in IT have the lowest completion rates, and little research has been published on professional, part-time IT doctorates. Unlike current conceptual frameworks which focus on inexperienced graduates, CoP offers a pedagogical framework that better addresses the workplace experiences of mid-career professionals undertaking doctoral studies.

\section{The DIT}

This section puts the Doctor of Information Technology (DIT) into its broader context. It begins with a review of IT doctorates. From there the Australian context of similar courses is sketched. 
The DIT has evolved since its inception less than two decades ago. One innovative design is a Doctor of Science, which involved an "instruction-delivery distance learning approach" (Hoganson \&Amoroso, 2011, p. 311). Another example is that of Pace University, whose course design is based on six agile principles (Grossman et al., 2011, p. 139). Still another program requires weekend face-to-face meetings, and has distance interaction between such weekends, following a more traditional doctoral education model of full-time, on-campus students, but allowing for the fact that these students are professionals who work full-time (Merritt et al., 2004). The latter course is one of the earliest in IT, having begun in 1999, and is one of the few where there have been attempts to evaluate its efficacy. The academic quality of the dissertations was evaluated by objective reviewers who were tasked with evaluating "the meaningfulness of the problem, the methodological strength of the investigation, and the readability of the presentation" (Merritt et al., 2004, p. 44). That study reported results for the 2001 cohort, who graduated in 2004 . Although their stated aim was $100 \%$ retention, of the 20 students who started, only six graduated. The objective reviewers, on a rating scale to a maximum of 4.0, rated those six as 3.4 for significance of the problem, 3.3 for strength of the investigative methodology and 3.5 for readability (Merritt et al., 2004, p. 45). That study was conducted 5 years into their new program, with a later study conducted in the 11th year revealing that over the period of those 11 years completion rates had averaged 52\% (Grossman et al., 2011).

Charles Sturt University (CSU), which for several years has been the national leader in parttime, post-graduate IT education, saw the DIT as a way to build on that leadership. For example, the DEEWR uCube statistics (http://highereducationstatistics.education.gov.au/) revealed that of the 3,821 part-time, post-graduate IT 2013 enrolments across Australia, not only was CSU the leader with 566 new enrolments, but its closest rival, the University of Technology, Sydney, had 372, demonstrating that CSU is not just leading by a small margin. Of the 39 Australian universities, only four others offer a professional doctorate in IT: Queensland University of Technology, University of New South Wales (UNSW Canberra at ADFA), and Edith Cowan University, and Murdoch University. Three others have been discontinued: Monash University, University of South Australia, and Federation University Australia. The UNSW course is only offered to full-time domestic students; the other three universities require international students to be full-time on campus, but allow domestic students a part-time option. Murdoch University does not offer all their coursework subjects in distance mode, further demonstrating the university preference for full-time, on-campus study.

\section{The Context of This Study: The DIT Structure at CSU}

Although the CSU DIT has existed for over a decade, it recently underwent a significant redevelopment. The fees, course structure, coursework to research components and all other aspects of the DIT have been considered and redesigned, to make it competitive when compared to other offerings within Australia. Wide industry consultation took place, to ensure the relevance of the applied nature of the course.

As illustrated in Table 1, the new post-masters DIT is not a single award. As with the course at Pace University (Grossman et al., 2011, p. 139) mentioned above, the DIT also follows an agile design philosophy, with four of those principles reflected in Table 1. Firstly, early and continuous delivery of valuable product, reflected in that students can exit in three stages. Also within each of the first two years of coursework students are guided to develop an article and submit it to a conference or journal. Secondly, welcoming changed requirements, even late in development, reflected in that few students complete the course in the precise area of study that drew them to enroll in the first place. Instead, as the course progresses, their understanding and interests change, as do available resources, access to data and workplace and life circumstances. Thirdly, delivering working product frequently, which is reflected in the paper development each year. Each paper spans the coursework subjects of that year, with progressive iterations of the paper, helping students through writing to explore research and their chosen topic. Finally, measuring progress primarily through useful deliverables, is also 
seen in the coursework component, not only through the papers, but in that a credit average is required to progress from first to second year and from second year to the dissertation stage. Therefore, aside from the student choosing to take out a lesser award than the doctorate, if they successfully complete a year but fail to achieve a credit average, then they have to exit with the lesser award.

\begin{tabular}{|l|l|l|}
\hline Subjects & Award & $\begin{array}{l}\text { Study } \\
\text { load }\end{array}$ \\
\cline { 1 - 2 } ITC711 Research Issues in IT & $\begin{array}{l}\text { Graduate Certificate in Computing } \\
\text { Research }\end{array}$ & Year 1 \\
\cline { 1 - 2 } ITC712 Conducting a Research Project in IT & Master of Computing Research & Year 2 \\
\cline { 1 - 2 } ITC713 Research Project Plan in IT & Desearch Project Development in IT \\
\cline { 1 - 2 } $\begin{array}{l}\text { ITC715 Thesis (Full-time) or ITC716 Thesis (Part- } \\
\text { time) }\end{array}$ & Doctor of Information Technology & Years 3 to 6 \\
\hline
\end{tabular}

Table 1: Structure of the Doctor of Information Technology course (2012 onwards)

Of the 36 applications received for the intake in the first session of 2012, 28 were domestic and 8 international. 28 offers were made (24 domestic, 4 international), resulting in 22 acceptances (20 domestic, 2 international), with 4 of those deferring. Of the 18 students who started in the first session of 2012, 5 students withdrew and 2 failed the first subject; both students who failed chose not to re-enroll, but withdrew from the course. That left 11 students who progressed to the second subject, ITC712. Three more withdrew before the end of the first year, and two exited (with lesser awards) before entering the dissertation phase. In 2014 the remaining six all entered their thesis component; one of those six transferred into a $\mathrm{PhD}$, due to changing career aspirations during the coursework stages, which resulted in a desire to become an academic. It should be noted that although all DIT students are part-time, it is possible to do the thesis component in full-time mode; for instance, one student works for a university (not CSU) and will be full-time for six months during their thesis component, whilst on sabbatical from that university.

Candidate selection is a critical factor to successful completion (Cantwell, Scevak, Bourke, \& Holbrook, 2012; Kiley, 2011). An assessment has to be made about the ability of the student to successfully complete. The above figures show that of the 36 initial applicants, 28 offers were made and 10 failed to complete the first year, signaling that the initial screening process was inadequate. Screening of applicants has improved significantly from that first intake. From the second 2012 intake to the second intake 2014, the enrolments have been 8, 5, 3,14,7, and the attrition (withdrawal or failure) has been 2,1,0,4, and 1 respectively. However, attrition and successful completion need to be distinguished. That is, few students now leave in the first year. However, because they can exit at 2 points prior to achieving their doctorates, those that do, have not attained the doctorate, but neither do they fit in traditional notions of 'attrition', in that they leave with a lesser award. Thus attrition in the CSU DIT only relates to those who leave in the first year of their course. In other words, when comparing the DIT to a course such as the Unisa or Pace University ones cited above, although our attrition rates are significantly lower than theirs, it does not necessarily mean that our success at doctoral completions will be better.

Each DIT student is appointed an industry co-supervisor. This serves two functions: firstly it provides a strong industry focus, by someone who has extensive, practical experience in the discipline area; secondly, it is a strategy to increase supervisory capacity. By restricting principal supervision to academics and co-supervision to industry experts, who have mentoring and supervisory expertise, but are not required to have a $\mathrm{PhD}$, the strong industry link sought by students is provided, whilst still ensuring that the research aims of the award are achieved. In addition to the immediate supervisors, the wider institutional supports effectively extend the supervisory team, and help to achieve a CoP that combines industry and research in an effective strategy. 


\section{Methodology}

The project followed an interpretivist, constructivist approach which sought to improve completion rates in the DIT specifically, as well as in IT doctoral research generally. The research questions were: How can successful student progression be facilitated? Which strategies and resources are required for successful student progression?

The project took place in the second half of 2012, when the focus was solely on the DIT, and in the first half of 2013, when the focus widened (as part of the original design of the study) to include other IT doctoral students and wider institutional doctoral support personnel. CSU ethics approval was sought and granted for each of the two phases of the research.

\subsection{Sampling}

Interviewees were chosen on the basis of criterion sampling (Patton, 2002), which employs a particular set of criteria to guide participant selection. For example, supervisors included people with experience as principal supervisors, co-supervisors, supervisors who were supervising for the first time, people who had not yet had a student successfully complete their doctorate under that person's supervision, and people who had supervised at least one student to successful completion of their doctorate; all supervisors needed to be the principal or cosupervisor of at least one DIT student. The criterion for DIT students included students enrolled under the old DIT structure, those enrolled under the new 2012 structure, graduates of the DIT, students who had discontinued under the old structure, students who had discontinued under the new structure, and students who had deferred their DIT studies.

The 44 semi-structured interviews included 13 supervisors, eight DIT and six IT PhD students, and 17 support staff, representing every aspect of institutional support personnel for doctoral students, including disability support, library support, student services (such as for students from non-English speaking backgrounds), scholarship support, Sub-Deans for Graduate Studies, research office (RO) staff and DIT administrative officers (such as for enrolment and deferral procedures). Each interview was from 45 to 120 minutes duration, and used the same set of questions, although a few relating to supervisory experiences were adapted for interviews with support staff who did not have experience of supervision.

\subsection{Data analysis}

All the interviews were tape recorded and transcribed verbatim. The transcribed interviews were analysed using thematic (qualitative) analyses. The data analysis from both phases followed closely a process described by Morse (2008) who advocated that the researcher should start by identifying categories from the data, with themes developed later to tie the identified categories together. Data analysis was completed with the help of QSR NVivo 10, a software package for managing qualitative data. The unit of analysis was each individual interview document.

A total of 32 categories in five themes emerged. The following section draws on these findings to discuss the results, drawing on exemplary quotations to show supporting evidence from the data.

\section{Results and Discussion}

Improvements and impediments to completion rates can be seen in the following key areas. The first of these concerns retention.

\subsection{Retention}

As seen in the literature, students who graduate typically do well, but it is retention that is one of the largest contributors to poor completion rates (Kritzinger \& Loock, 2012; Merritt et al., 2004). Two retention issues were seen as significant in this study. Firstly, students need help in achieving a work-life-study balance. DIT students are typically high achievers in the workplace, used to juggling multiple projects. They come into the DIT expecting it to just be 
another project to manage. However the demands of the course and the nature of research, as well as the length of involvement in the DIT, make it very different from the typical projects that they are used to dealing with. First-year DIT students voiced concerns about inadequate ability to fit the requirements of the DIT into their busy work and family situations. One student with two young children said that she got into the habit of rising at 4 am, to have time to focus on the DIT. Another student stated that he has 4 hours per week of study leave from his employer, which on the one hand is wholly inadequate to do what the DIT demanded of him, and on the other hand was frequently infringed upon by his employer, as work deadlines required all employees to contribute/ be present. Related to this is the inadequacy of formal session deadlines in the coursework structure. A flexible approach might permit the extension of assessment commitments, to better accommodate the busy and pressured working lives of these students. One student withdrew from a subject in 2012 because unexpected work demanded his attention. Had he been able to delay submission of assessment tasks, he could have continued. Thus one area of focus for retention needs to address the work-life-study balance.

The agile course design, first seen in the Pace University course (Grossman et al., 2011), addresses another area of retention, namely the need to teach research skills by engaging students through early and continuous delivery of valuable products. Supervisors believed that it is important for student progression that they publish articles based upon their work to date.

For instance, a co-supervisor who had supervised one DIT to completion and was supervising a second DIT student:

The supervisor relationship had ended and I was just producing a few papers for a couple of journals, actually conferences. So I just feel that hasn't been exploited, it's the logical outcome and that needs to be, yeah just taught better.

A principal supervisor, who had supervised three $\mathrm{PhD}$ students to completion, was supervising six more, plus one DIT student, stated:

The publication of papers in my mind is a way of vetting it before you put it in. So you get some feedback from external people so you are on the right track.

The advantages of publication are numerous. Institutionally it helps lift the research quantum output. For supervisors co-publishing with their students, it lifted not only their publication rates, but because their students cited their supervisors, it also lifted the citation rates of the supervisors involved. For the students, having peer-reviewed publications during their DIT progression meant that thesis examiners could readily see that the research had already stood up to scrutiny in the wider research community, and thus increased the chances of a successful examination process. One student who dropped the DIT during the second year of coursework claimed that, had he been encouraged to publish his work from the first year (as is the case now with the new DIT structure), it would have shown him that his work was valued, it would have meant that he could in-part fulfill the purpose he had for doing the DIT which he claimed was to 'give back' to the ICT community, and he expressed the view that it would have helped him to build a portfolio that he could use to promote himself in the industry marketplace. One cautionary note from a research support person was that supervisors have to beware not to take away the voice of their student, as they guide them to write better. Finally, by involving students and supervisors together in a CoP that combines discipline-specific interests with a focus on writing, the university can increase its publication rate, whilst also building positive relationships between students and supervisors, as well as thus encouraging greater networking between students with each other and within CoPs at the university.

\subsection{Student engagement with supervisors}

As was true for the wider literature on doctoral supervision, the busy workloads of academics frequently result in inadequate contact with part-time distance students. Three supervisors stated that they met weekly with all their students, be they distance or full-time on-campus. The other supervisors had varying policies regarding contact with part-time students, ranging 
from every 2-3 weeks, to every two months, to whenever the student made contact with them. Examples include the following:

On average probably about every couple of weeks, usually by email and sometimes it's a flurry of email and sometimes one or other of us is off on their work commitments or whatever else. So it's probably on average, yeah about once every 10 days, once a fortnight there abouts. ... I haven't been at all uncomfortable or unhappy with the degree of contact. (Mid-career male DIT student)

The first couple of months ... on the phone. He called me on the phone and then it turned out to be Skype calls. ... every three weeks or so, I would say. (Overseas, midcareer female DIT student)

All supervisors received the same workload allocation for supervision, although those with weekly contact with students, which typically involved reviewing progress on a weekly basis and pre-reading of the student's latest work prior to the meeting, had a heavier workload. One situation was reported where no contact took place for six months, which was how long it took for the student to contact the supervisor. Intuitively one could imagine that student progression and engagement would be significantly better for students who met weekly or fortnightly with their supervisors (typically using Skype), than for students who met every two months or less often. Thus a strategy of supervisor-to-student communication needs attention, possibly in the form of a policy directive by the School.

The master-apprentice model derived from traditional $\mathrm{PhD}$ supervisory practices is reflected in the DIT. There were only two exceptions: in both cases these were overseas-trained academics, who brought with them to CSU what they valued from their overseas experience, namely team supervision, in which the co-supervisors (1 or 2 co-supervisors) are an integral part of the process and are expected to meet with the student every time the principal supervisor meets with them. Interestingly, however, one of the students interviewed was a student of one of these two overseas-trained supervisors, and that student expressed the view that they dealt mostly with the principal supervisor and rarely with the co-supervisor. Thus it seems that contradictory information is being reported by the supervisor and one of their students. Nonetheless, a strategy of collaborative supervision should be investigated further. There is evidence in the literature that collaborative supervision is increasingly being employed elsewhere to improve student progression (Berteau \& Villeneuve, 2006; Fenge, 2012), including inter-university collaborative supervision (Hammond, Ryland, Tennant, \& Boud, 2010; Malfroy, 2011). It also seems appropriate to the new DIT structure, which relies on the involvement of industry co-supervisors, who may have little experience in the supervision of research and thus would benefit by being part of a team approach to the supervision of their students.

Another area that students highlighted was the relationship between them and their supervisors. In several cases the supervisory team had undergone numerous changes. One graduate of the DIT stated that they had worked with six supervisors during the period of the degree. Three changes were beyond the control of theinstitution, in that one supervisor retired, another shifted to a different faculty, and another took a redundancy package. Furthermore, the student experienced a further delay when the final principal supervisor became severely ill and took seven months to recuperate, during which this student was left without adequate supervision, because the then co-supervisor, who did not have a $\mathrm{PhD}$, was unable to advise on the final write-up process, which was the stage that the student was at. With each change of supervisor came a change in focus, change in literature to review, and with the last, a change from quantitative to qualitative research. That student felt that the result was that the degree took two years longer than it would have otherwise. Although this may bean extreme situation, the frequent changes of supervision and the inadequacy of supervision during the coursework components of the course, were recurrent themes. For instance, one student dropped the DIT after experiencing a situation where his first supervisor left CSU after six months and the next supervisor retired within two months of taking over as the principal supervisor. Although CSU could not have foreseen that the initially appointed supervisor would leave the institution, CSU 
management would have been aware of the pending retirement of the second principal supervisor at the time of that person's appointment as this student's supervisor.

\subsection{Supervision appointment}

An inadequacy in preparing people for supervision was also identified. The strategies employed across the university sector for teaching academics how to supervise vary significantly. One person trained at a research intensive university stated that she had to be co-supervisor to an experienced principal supervisor for two years, sitting in on every consultation that person had with their students, before she was permitted to become a principal supervisor herself. That compares with the CSU policy of A and B registers. A person new to supervision attends a threehour seminar about the supervisory process at CSU and is then placed on the B register for 12 months, during which they can only be a co-supervisor. There is no standard for what happens during those 12 months and, as noted above, many principal supervisors refuse to involve cosupervisors at all, following the traditional master-apprentice model. Then after 12 months the academic can apply to be listed on the A register, and through the simple expedient of that application becomes eligible to be a principal supervisor. Intuitively one would have to assume that the depth of preparation differs significantly between the CSU approach and that of the CSU academic trained at a research-intensive university. This suggests that an institutional strategy needs to be investigated to improve preparation for principal supervision at CSU. Although there exists a nine point list of supervisor responsibilities and the RO makes supervisory training available throughout the year, using webinars, there is no compulsion on supervisors to participate in the training. In this researcher's own experience, no one has ever held me to account for how my supervision stacks up against the nine requirements.

Related to the last point is the strategy of supervisor appointment for the DIT. Under the old structure supervisors were appointed to students, without the student's input. In two cases students were told by their supervisors not to contact them, because the work that the students wanted to research had nothing of interest to these supervisors. In other cases, as indicated above, students experienced multiple changes of supervision, until either they adapted their research to suit the supervisor's interests, or they found a supervisor with an interest in the student's area of interest. A better approach would be to enable a mutual choosing. To this end, and similar to the Pace University example of symposiums as a deliberate strategy of course design (Grossman et al., 2011), the new DIT structure includes an annual doctoral symposium which provides staff and students an opportunity to meet.

\subsection{Feedback on progress}

There is a need for policies around feedback and guidance. Subject coordinators are understandably focused on the assessment requirements in their respective subjects. Their feedback and guidance relates specifically to their subject. But two of the students who dropped the DIT and one who graduated from it stated that the big picture was missing. They needed someone to guide them through the process, to help them see how what was being done in individual subjects was also building their skill sets for the eventual thesis. One such strategy of feedback and guidance is that of mentoring. Under the old DIT structure supervisors were appointed from day one, but effectively had little or no involvement with students, and it appeared to students that supervisors were not interested in them until they had completed the coursework components and were ready to begin the thesis work. Under the new structure of the DIT, students are similarly claiming that they are having to re-tell their story, their goals and ambitions in research to each subject coordinator, and that there is no single person who seems to know their personal aspirations and is willing to provide feedback and guidance. But the appointment of mentors to small groups of students in the first year of the DIT would solve this. Such a mentor would remain a student's mentor until a supervisor is appointed mid-way through the second year. Again this notion of mentoring is supported by the conceptual CoP framework, in that it helps to build a small community of practice, involving 4-6 students with similar interests, methodologically or discipline-based, with at least one staff member who is an expert in that area. 
Other strategies to improve feedback and guidance relate to adequate provision of subjectbased assessment criteria and resources to complete tasks. For the research proposal subject under the old DIT structure, no exemplars were given and one student dropped the course when receiving a poor grade for that assessment task, despite having approached numerous sources within CSU for help, including the subject coordinator. The student stated that the assessment of his submission clearly showed that certain things had been expected, yet those expectations had not been communicated. In undergraduate subjects CSU policy for assessment criteria requires clarity of assessment expectations as part of the Subject Outline, which students receive upon enrolment, yet that does not appear to be the case for doctoral coursework.

\subsection{Student engagement in the course}

Student engagement is required from the start. The present DIT design starts with ITC711, which introduces students to research, but in a general and generic fashion. Two students who completed the first year of the new DIT commented that ITC711 was their first taste of the DIT and that the subject was a turn-off. They would have preferred to see right from the start how their new research studies could be relevant to their workplace, rather than have to take it on faith that the eventual thesis work would have an applied and workplace relevant focus.

\subsection{Contribution}

The following is typical of DIT students, this from a man in his late 50s:

(with his supervisor) that was a brain storming at its very best and she was great to bounce ideas off and talk about things - that really pressed my buttons. ... as mature age students which I suspect most of the DIT students would be - there is no age difference and therefore the if you like a level playing field in terms of the interaction with staff is really empowering - not to be treated as students but to be treated as peers who have good valuable contributions to make. That's why most folk I would think do it because they feel they have something to contribute and the DIT is a way of achieving that outcome.

The concept of contribution requires further investigation. All the DIT students interviewed envision their doctorate as a way of 'giving back'. They felt as though they had something to contribute. However, that desire on the part of these mature-age, industry-savvy students is an untapped resource. That desire suggests that these students are a rich source of ideas, research possibilities and other opportunities.

\subsection{Student involvement in institutional CoPs}

CSU has various institutional support mechanisms that are geared to doctoral research including, but not specifically aimed at, professional doctorates. As mentioned in the introduction above, there are numerous expressions of professional doctorates. The Faculty of Education had one, although it has been discontinued. The Faculty of Science has several, particularly in areas related to medical and agricultural research. Thus even though the new DIT program structure is unique within CSU, many of the doctoral support mechanisms are helpful to the DIT. Examples of support include:

Yesterday I did one, an induction yesterday for $17 \mathrm{PhD}$ students ... give them directional information particular to them you don't have time in 20 minutes, whereas an induction that we do with the one-on-one might go for an hour, an hour and a half where you actually go into it in a bit more detail, point out things that are relevant to them, rather than general stuff. (Library research support staff)

I'm enjoying what I'm doing but keeping up with the workload in conjunction with a seriously demanding job is tough, so without - I think I would find it much harder without the support that I'm getting. (DIT student)

(CSU has) been good at developing its support mechanisms. And the support that we have through the structural things like sub Deans of research and research 
management committees and all of those sort of things. But right down to being, you know communicative to the students and making them aware, sort of all of the things that are here to support you, it's actually quite large. (DIT and PhD Supervisor)

University research supports include the RO, library staff whose function is supporting research, and the Learning Skills unit. Faculty supports are predominantly available through Sub-Deans for Graduate Studies, their administrative support personnel and the resources they make available. School supports are provided through doctoral course coordinators, which in the case of the DIT involves the DIT Course Coordinator. Thus from an institutional perspective, what has been described in the literature as strategies of collaborative supervision (Borrell-damian et al., 2010) and what can be seen as a CoP is in evidence.

In CoP terms, the RO primarily see their training role as encouraging a research culture amongst staff, that is, of supporting a community of practice for research active staff. Students are welcome to attend research training events, but those events are designed to benefit research-active staff, not students. Aside from their own training, they also facilitate access to research training provided through a consortium of universities. At present it appears that industry and other non-CSU supervisors are not included in this training. However, given that such training is open to doctoral students if they express an interest in participating, it should also be possible to include industry supervisors, should they wish to participate. Thus the RO focus can been seen in terms of what in the literature is described as strategies for training in supervision (Amundsena \& McAlpine, 2009; Kiley, 2012; McAlpine \&Amundsen, 2012). That body of literature also focuses attention on the need to particularly provide training for early career researchers and for people new to academia (Blass et al., 2012; Christine Halse, 2011; C. Halse \& Malfroy, 2010).

However, as seen above, there is a disconnect in professional development. That disconnect is between initial training for supervision, to rapidly build supervisory capacity, and large supervisory workloads that make accessing ongoing training difficult to attend, even virtually. For instance, two people new to supervision stated:

...there's no real follow-up training, like we don't have a mandatory ongoing system of $\mathrm{PD}$ or, you know, professional development throughout the year (Supervisor of $2 \mathrm{PhD}$ and 3 DBA and 1DIT)

There is some workshops or supervision, but I think that is not very helpful. (Supervisor of $2 \mathrm{PhD}$ and $5 \mathrm{DIT}$ )

It's should never be just the research students, they should have an opportunity to get to interact certainly ... But I'm actually thinking of the research students in the research community and that includes supervisors and others, because supervisors get very little training. ... One of the reasons why CSU has gone the way it has, is simply it has, it's just not - it doesn't have enough supervisors. It wants to get more and more students in; it doesn't seem to be wanting to put the investment into really developing quality supervisors, so a lot of people get thrown into the deep end. In some cases, and I think that whole idea of experts and novices and different communities of practice ...experienced and non experienced supervisors working together in expressly in communities of practice. (Research support staff member; former doctoral supervisor)

J ust as the RO is promoting a CoP for research staff, so too an initiative of the FOB Sub-Dean Graduate Studies to provide intranet-based resources to supervisors has proved popular. Interviews with supervisors indicated that the majority appreciated this as a significant boost to helping them to become better supervisors. The resources made available through that site have been helpful in terms of understanding policies, overcoming challenges, and feeling part of a CoP, that is, of being part of something bigger and not being alone in dealing with supervisory issues that arise.

The RO have in the past held doctoral workshops for students, but found that they were poorly attended. One example was a generic online webinar, which was only attended by 20 doctoral students from across the university, and not a single professional doctorate student was among 
them. Similarly, attempts by the RO to involve doctoral students in online forums have resulted in poor student engagement. This has consequently been devolved to the faculty level, on the assumption that this way there will be a greater discipline-specific appeal to students. This is not unique to CSU. For example, the largest doctoral study yet completed, which involved over 17,000 survey respondents, reported that over $70 \%$ did not collaborate online, with $58 \%$ not having posted online contributions to institutional initiatives aimed at helping students to network (Anonymous, 2012, p. 37). In that report the authors went on to recommend that institutional supports be discipline-based, rather than attempt to bring all doctoral students together.

Retention, student engagement and institutional support are interdependent. As one research student support officer said, students need to learn to manage their supervisors, not just wait to be managed by them. The DIT is delivered within the Faculty of Business (FOB), which has 130 students in various doctoral programs including $\mathrm{PhD}, \mathrm{DBA}$ and DIT. Thirty of these were contacted by the Sub-Dean Graduate Studies. Those students were predominantly working full-time and expressed the desire not to be in contact with other doctoral students. That has implications for faculties wanting to create a CoP involving their students. Again this is not unique to CSU. The survey of over 17,000 doctoral students, mentioned earlier, found that whilst students expressed in-principle support for sharing research between students, when it came to making their own research available to other students, they were reluctant to do so, preferring to work alone. A strategy of developing collaborative research teams amongst doctoral students did not appeal to over $90 \%$ of respondents (Anonymous, 2012, p. 41).

\begin{tabular}{|c|c|c|c|c|}
\hline Area & Aids to progression & $\begin{array}{l}\text { Barriers to } \\
\text { progression }\end{array}$ & Policy implications & Further research \\
\hline Retention & $\begin{array}{l}\text { - Agile course design } \\
\text { - Writing papers along } \\
\text { the doctoral journey }\end{array}$ & & $\begin{array}{l}\text { - Flexible delivery to } \\
\text { improve work-life- } \\
\text { study balance }\end{array}$ & \\
\hline $\begin{array}{l}\text { Student } \\
\text { engagement with } \\
\text { supervisors }\end{array}$ & $\begin{array}{l}\text { - Weekly or fortnightly } \\
\text { contact }\end{array}$ & $\begin{array}{l}\text { - } \quad \text { Contact less } \\
\text { frequent than } 3 \text { weeks } \\
\text { - } \quad \text { Staff workload } \\
\text { - } \quad \text { Dependence on a } \\
\text { sole supervisor } \\
\text { - } \quad \text { Change of principal } \\
\text { supervisor }\end{array}$ & $\begin{array}{l}\text { - Frequency of } \\
\text { contact } \\
\text { - Supervisor } \\
\text { (mentor) guidance } \\
\text { during the } \\
\text { coursework } \\
\text { component }\end{array}$ & $\begin{array}{l}\text { - Collaborative } \\
\text { supervision } \\
\text { - Impact of frequency } \\
\text { of contact on student } \\
\text { engagement and } \\
\text { progression }\end{array}$ \\
\hline $\begin{array}{l}\text { Supervision } \\
\text { appointment }\end{array}$ & $\begin{array}{l}\text { - Opportunities for } \\
\text { students and potential } \\
\text { supervisors to meet and } \\
\text { get to know each other }\end{array}$ & $\begin{array}{l}\text { - Supervisor has } \\
\text { little interest in topic } \\
\text { of student }\end{array}$ & $\begin{array}{l}\text { - Supervision } \\
\text { training } \\
\text { - Transition for co- } \\
\text { supervisor to } \\
\text { principal supervisor } \\
\text { - Mutual choosing of } \\
\text { student and } \\
\text { supervisors }\end{array}$ & $\begin{array}{l}\text { - How compliance } \\
\text { with supervision policies } \\
\text { can be improved }\end{array}$ \\
\hline $\begin{array}{l}\text { Feedback on } \\
\text { progress }\end{array}$ & & $\begin{array}{l}\text { - Coursework } \\
\text { assessment } \\
\text { expectations need to } \\
\text { be clearly } \\
\text { communicated }\end{array}$ & $\begin{array}{l}\text { - Feedback and } \\
\text { guidance } \\
\text { - Mentor during } \\
\text { coursework }\end{array}$ & \\
\hline $\begin{array}{l}\text { Student } \\
\text { engagement in } \\
\text { the course }\end{array}$ & $\begin{array}{l}\text { - Early engagement is } \\
\text { important to retention }\end{array}$ & $\begin{array}{l}\text { - Address the } \\
\text { disconnect between } \\
\text { initial coursework } \\
\text { research subject and } \\
\text { their (often technical) } \\
\text { work }\end{array}$ & & \\
\hline Contribution & $\begin{array}{l}\text { - Making a } \\
\text { contribution is } \\
\text { motivating to these } \\
\text { mature are students } \\
\text { - Writing papers is a } \\
\text { way of 'giving back' }\end{array}$ & & & $\begin{array}{l}\text { - How to tap this } \\
\text { resource }\end{array}$ \\
\hline $\begin{array}{l}\text { Student } \\
\text { involvement in } \\
\text { institutional CoPs }\end{array}$ & $\begin{array}{l}\text { - Post induction, one- } \\
\text { on-one sessions between } \\
\text { research library staff } \\
\text { and doctoral students }\end{array}$ & $\begin{array}{l}\text { - } \quad \text { Heavy staff } \\
\text { supervisory workloads } \\
\text { - Demanding } \\
\text { workplaces of DIT } \\
\text { students }\end{array}$ & $\begin{array}{l}\text { - Supervisor } \\
\text { workload } \\
\text { management }\end{array}$ & $\begin{array}{l}\text { - How to encourage } \\
\text { part-time students to } \\
\text { engage in CoPs }\end{array}$ \\
\hline
\end{tabular}

Table 2: Factors for improving retention and progression in computing doctorates 
As seen above, seven areas have been identified as requiring focus in order to improve completion rates in professional IT doctorates. They are summarised in Table 2, which highlights key aids and barriers to progression, implications for institutional policy and areas for further research.

\section{Conclusions}

Improving the completion rates of students undertaking a professional doctorate in IT has multiple benefits, and not only for the students. The principal attraction of doctoral students for a University is not the money that they bring in, but research outputs. In addition to the contribution that this makes to the wider society and to the industry, such outputs lead to increased reputation, which in turn attracts more undergraduate students. Doctoral studies have focused on the $\mathrm{PhD}$, and on supervision practices, as opposed to student perspectives, and discipline-based doctoral studies have rarely included IT. This is despite the wide acceptance that doctoral students are a key part of the publishing strategy of a university. Although the literature shows that in professional IT doctorates the completion rates are poor, particularly for part-time students, lessons learned from interviews have resulted in the identification of key strategies aimed at mitigating particularly the risk of attrition, because the literature supports the notion that if students complete, then the quality of outcomes are comparable to conventional research-oriented doctorates, which in turn supports the contention that the professional doctorate is a 'research doctorate'.

\section{Acknowledgment}

This research was supported by two Flexible Learning Institute fellowships from the CSU Deputy Vice-Chancellor (Academic), which bought out half my teaching for two semesters.

\section{References}

Alpert, F., \&Kamins, M. A. (2004). Doctoral coursework is needed in Australasia. Australasian Marketing J ournal, 12(1), 66-72.

Amundsena, C., \& McAlpine, L. (2009). 'Learning supervision': Trial by fire. Innovations in Education and Teaching International, 46(3), 331-242.

Andrew, M. (2012). Supervising doctorates at a distance: Three trans-Tasman stories. Quality Assurance in Education, 20(1), 42-53.

Anonymous. (2012). Researchers of Tomorrow: the research behaviour of Generation Y doctoral students. London.

Barnett, R., \& Coate, K. (2005). Engaging the Curriculum in Higher Education. Maidenhead: McGraw-Hill.

Berteau, G., \& Villeneuve, L. (2006). Integration of the learning process and the group development process in group supervision. GroupworkAn Interdisciplinary J ournal for Working with Groups, 16(2), 43-60.

Blass, E., J asman, A., \& Levy, R. (2012). Supervisor reflections on developing doctoralness in practice-based doctoral students. Quality Assurance in Education, 20(1), 31-41.

Borrell-damian, L., Brown, T., Dearing, A., Font, J ., Hagen, S., Metcalfe, J ., \& Smith, J . (2010). Collaborative Doctoral Education: University-Industry Partnerships for Enhancing Knowledge Exchange. Higher Education Policy, 23(4), 493-514.

Cantwell, R. H., Scevak, J. J., Bourke, S., \& Holbrook, A. (2012). Identifying individual differences among doctoral candidates: A framework for understanding problematic candidature. International Journal of Educational Research, 53(0), 68-79. doi: 10.1016/j.jjer.2012.02.001 
Crossouard, B. (2008). Developing alternative models of doctoral supervision with online formative assessment. Studies in Continuing Education, 30(1), 51-67. doi: 10.1080/01580370701841549

Crossouard, B., \& Pryor, J . (2009). Using email for formative assessment with professional doctorate students. Assessment \& Evaluation in Higher Education, 34(4), 377-388. doi: 10.1080/02602930801956091

Cumming, J., \& Kiley, M. (2011). Research Graduate Skills Project. In T. Gale \& K. Parker (Eds.), Good practice report Student transition into higher education: Department of Education, Employment and Workplace Relations.

Cuthbert, D. (2008). Beyond the doom and gloom. Campus Review.

Engebretson, K., Smith, K., McLaughlin, D., Seibold, C., Terrett, G., \& Ryan, E. (2008). The changing reality of research education in Australia and implications for supervision: a review of the literature. Teaching in Higher Education, 13(1), 1-15. doi: 10.1080/ 13562510701792112

Erichsen, E. A., Bolliger, D. U., \& Halupa, C. (2012). Student satisfaction with graduate supervision in doctoral programs primarily delivered in distance education settings. Studies in Higher education, 1-18. doi: 10.1080/ 03075079.2012.709496

Fenge, L. A. (2012). Enhancing the doctoral journey: The role of group supervision in supporting collaborative learning and creativity. Studies in Higher education, 37(4), 401-414.

Fink, D. (2006). The professional doctorate: It's relativity to the $\mathrm{PhD}$ and relevance for the knowledge economy. International journal of doctoral studies, 1, 35- 44.

Green, B. (2012). Addressing the curriculum problem in doctoral education. Australian universities' review, 54(1), 10-18.

Grossman, F., Tappert, C., Bergin, J . O. E., \& Merritt, S. M. (2011). A Research Doctorate for Computing Professionals. Communications of the ACM, 54(4), 133-141. doi: $10.1145 / 1924421.1924450$

Guan, Y., Guo, Y., Bond, M. H., Cai, Z., Zhou, X., Xu, J ., Ye, L. (2014). Newjob market entrants' future work self, career adaptability and job search outcomes: Examining mediating and moderating models. Journal of Vocational Behavior, 85(1), 136-145. doi: http:// dx.doi.org/ 10.1016/j.jvb.2014.05.003

Halse, C. (2011). 'Becoming a supervisor': the impact of doctoral supervision on supervisors' learning. Studies in Higher education, 36(5), 557-570. doi: 10.1080/03075079.2011.594593

Halse, C., \&Malfroy, J . (2010). Retheorizing doctoral supervision as professional work. Studies in Higher education, 35(1), 79-92.

Hammond, J ., Ryland, K., Tennant, M., \&Boud, D. (2010). Building Research Supervision and Training across Australian Universities. Strawberry Hills, NSW: Australian Learning and Teaching Council.

Hirschheim, R., \&Klein, H. K. (2012). A Glorious and Not-So-Short History of the Information Systems Field. J ournal of the association for information systems, 13(4), 188-235.

Hoganson, K., \& Amoroso, D. (2011). Inter-disciplinary doctor of science with computer science and information systems.

Kiley, M. (2011). Where are our doctoral candidates coming from and why? : ALTC.

Kiley, M. (2012). ALTC:Coursework in Australian doctoral education: what's happening, why, and future directions? , from http:// www.olt.gov.au/project-coursework-australiandoctoral-education-whataposs-happening-why-and-future-directions-2012 
Kimmerle, J., Thiel, A., Gerbing, K., Bientzle, M., Halatchliyski, I., \& Cress, U. (2013). Knowledge construction in an outsider community: Extending the communities of practice concept. Computers in Human Behavior, 29, 1078-1090.

Kritzinger, E., \& Loock, M. (2012). A critical investigation into the current shortage of information technology postgraduates produced by UniSA. Paper presented at the ODL12 Conference.

Lee, A. (2009). Some implications of European initiatives for doctoral supervision EUA Bologna Handbook. Making Bologna Work. European University Association.

Lee, A., Brennan, M., \& Green, B. (2009). Re-imagining doctoral education: Professional Doctorates and beyond. Higher Education Research \& Development, 28(3), 275-287.

Lee, A., Green, B., \&Brennan, M. (2000). Organisational knowledge, professional practice and the professional doctorate at work. In J . Garrick \& C. C. Rhodes (Eds.), Research and Knowledge at Work: Perspectives, Case-Studies and Innovative Strategies (pp. 117136). London: Routledge.

Lee, A., \& McKenzie, J . (2011). Evaluating doctoral supervision: tensions in eliciting students' perspectives. Innovations in Education and Teaching International, 48(1), 69- 78.

Loftus, S. (2010). Exploring communities of practice. In J . Higgs, D. Fish, I. Goulter, S. Loftus, J . Reid \& F. Trede (Eds.), Education for future practice. Rotterdam, The Netherlands: Sense Publishers.

Malfroy, J . (2011). The Impact of University-Industry Research on Doctoral Programs and Practices. Studies in Higher education, 36(5), 571-584.

McAlpine, L., \& Amundsen, C. (2012). Challenging the taken-for-granted: How research analysis might inform pedagogical practices and institutional policies related to doctoral education. Studies in Higher education, 37(6), 683-694.

McCallin, A., \& Nayar, S. (2012). Postgraduate research supervision: A critical review of current practice. Teaching in Higher Education, 17(1), 63-74.

Merritt, S. M., Stix, A., Sullivan, J . E., Grossrnan, F., Tappert, C. G., \& Sachs, D. A. (2004). Developing a professional doctorate in computing: A fifth-year assessment. Paper presented at the ITiCSE 2004 Conference, 28-30 J uly 2004, Leeds.

Metcalfe, M., \& Kiley, M. (2000). Arguing for PhD Coursework. Australasian J ournal of Information Systems, 7(2), 52-59.

Morse, J. M. (2008). Confusing categories and themes. Qualitative Health Research, 18(6), 727-728.

Ng, T. W. H., \& Feldman, D. C. (2014). Subjective career success: A meta-analytic review. J ournal of Vocational Behavior, 85(2), 169-179. doi: http:// dx.doi.org/ 10.1016/j.jvb.2014.06.001

Pavlova, M. K., \& Silbereisen, R. K. (2014). Coping with occupational uncertainty and formal volunteering across the life span. J ournal of Vocational Behavior, 85(1), 93-105. doi: http:// dx.doi.org/ 10.1016/j.jvb.2014.05.005

Richards, D., \& Marrone, M. (2014). Identifying the Education Needs of the Business Analyst: An Australian Study. Australasian J ournal of Information Systems, 18(2), 165- 186.

Schön, D. A. (1987). Educating the reflective practitioner: Towards a new design for teaching and learning in the professions. San Francisco: J ossey-Bass.

Smallwood, S. (2004). Doctor Dropout. Chronicle of Higher Education.

Sowell, R. (2008). Ph.D. Completion and Attrition: Analysis of Baseline Data. Columbia: 
Copyright: (C) 2015 Burmeister. This is an open-access article distributed under the terms of the Creative Commons Attribution-NonCommercial 3.0 Australia License, which permits non-commercial use, distribution, and reproduction in any medium, provided the original author and AJ IS are credited.

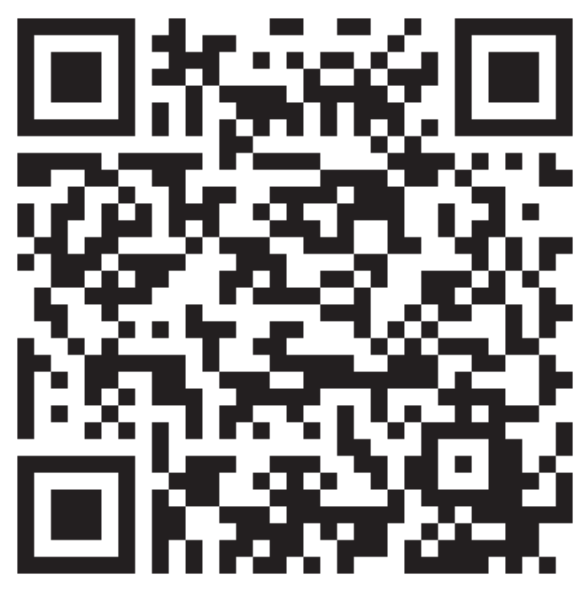

